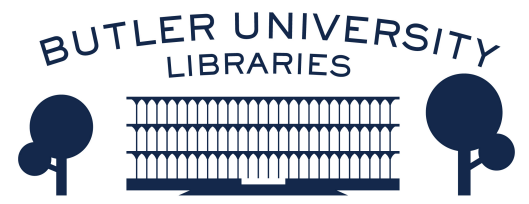

Journal of Hindu-Christian Studies

January 2004

\title{
Dialogue 'On The Ground': The Complicated Identities and the Complex Negotiations of Catholics and Hindus in South India
}

Selva J. Raj

Follow this and additional works at: https://digitalcommons.butler.edu/jhcs

Part of the Religion Commons

\section{Recommended Citation}

Raj, Selva J. (2004) "Dialogue 'On The Ground': The Complicated Identities and the Complex Negotiations of Catholics and Hindus in South India," Journal of Hindu-Christian Studies: Vol. 17, Article 7.

Available at: https://doi.org/10.7825/2164-6279.1316

The Journal of Hindu-Christian Studies is a publication of the Society for Hindu-Christian Studies. The digital version is made available by Digital Commons @ Butler University. For questions about the Journal or the Society, please contact cbauman@butler.edu. For more information about Digital Commons @ Butler University, please contact digitalscholarship@butler.edu. 


\title{
Dialogue 'On The Ground': The Complicated Identities and the Complex Negotiations of Catholics and Hindus in South India
}

\author{
Selva J. Raj \\ Albion College
}

INTERRELIGIOUS dialogue is a vital theological concern for the Catholic Church in India. Over the past three decades, church leaders (Amalorpavadoss 1978), progressive theologians (Amaladoss 1979), and maverick monastics (Griffiths 1982) have experimented with various models and forms of interreligious dialogue. Quite distinct from these contrived institutional initiatives is the dynamic of intimate, subtle, and spontaneous ritual exchange and dialogue between ordinary Hindus and Catholics occurring in the arena of popular piety and rituals at the grassroots level often in opposition to institutional norms and directives - that may be described as "dialogue on the ground." In light of ethnographic research at the shrine of St. Antony at Uvari in Tamil Nadu - that serves as a representative sample of regional shrines in rural south India - this essay focuses on the logic and grammar of a specific public ritual locally known as asanam as an illustrative case-study of the 'dialogue on the ground,' delineates the social and religious themes embedded in this ritual, and reflects on its implications for interreligious dialogue.

The Shrine, The Saint, and the Devotees
A. Shrine
The shrine of St. Antony at Uvari on the Pearl Fishery coast, situated thirty miles north of Kanya Kumari at the tip of the Indian peninsula, is a popular Catholic shrine in south India. Known as the "Padua of the East," Uvari is a coastal village of coconut trees and fishing boats situated on the shores of the Bay of Bengal. Its five- hundred plus Catholic families of the Parava (fishing) caste group proudly trace their Catholic heritage to the missionary work of stalwarts like St. Francis Xavier who is said to have spent several days in the village during one of his missionary trips. Though

Selva J. Raj, who received his Ph.D. in History of Religions from the University of Chicago, is Chair and Stanley S. Kresge Associate of Professor of Religious Studies at Albion College. A Past-President of the Society for Hindu-Christian Studies, he is a Co-Chair of the Comparative Studies in Religion Section of the American Academy of Religion and current President of the Midwest Region of the American Academy of Religion. His research interests are in the area of ritual exchange between Hindus and Catholics in India, Hindu women saints, tribal religions, and contemporary women's movements in India. Author of several articles, he has co-edited two volumes: (with Corinne Dempsey) Popular Christianity in India: Riting Between the Lines (SUNY: 2002) and (with William Harman) Dealing with Deities: The Ritual Vow in South Asia (SUNY: forthcoming in 2004). Currently he is co-editing, with Corinne Dempsey, Ritual Levity, Ritual Play in South Asian Traditions. He is also working on a monograph titled The Dialogue of Rituals: Religion of Tamil Catholics in South India. 
situated in a caste-conscious Catholic village, this rural shrine attracts thousands of devotees of diverse religious and caste identities who fulfil various vow rituals collectively known as asanam that include but are not limited to - hair-shaving, earpiercing, ritual bathing, and animal sacrifices.

Four towering churches - including a church built in the shape of a ship bearing an airplane - dedicated to four different Catholic saints dominate Uvari's physical and religious landscape. Among these four churches the recently renovated shrine of St. Antony is undoubtedly the most prominent when measured by the number of pilgrims it attracts and the wondrous miracles attributed to its patron saint. While many south Indian Catholic shrines - like the popular shrine of Vellankanni in northern Tamil Nadu - are known for fertility and healing, the shrine of St. Antony is regarded by many pilgrims Catholics and Hindus alike - as the preeminent site for miraculous healing for those suffering from demonic possessions, various forms of black magic and sorcery, and psychological distress. The old men and women of the village never tire telling pilgrims and visitors the Uvari legend that recounts the shrine's humble yet wondrous beginnings and the powerful miracles attributed to its patron saint.

Marion, an eighty-year-old retired catechist, enthusiastically recounted this legend to me. Long, long ago, nearly three or four hundred years ago - so goes the legend - Uvari had a small harbor where local villagers would trade with the incoming ships. The crew of a Portuguese ship approaching Uvari contracted cholera. A sculptor on board the ship began chipping a block of wood and carved the image of St. Antony. No sooner than he completed the sculpture the entire crew was miraculously saved from cholera. The ship was docked at Uvari. In gratitude for the miracle, the sculptor and the sailors installed the miraculous wooden statue on the shores of Uvari against the backdrop of a huge rock.
Around the eighteenth century, said Marion, a modest hut made of coconut leaves was built to house the wooden statue of St. Antony. A Hindu family looked after the hut for several generations until the Catholic Church took it over from the Hindu family. A full-fledged shrine dedicated to St. Antony was built in the 1940s. It was fully remodeled in 2003.

Uvari residents assert that the wooden statue of St. Antony enshrined on the altar is the same wooden statue installed by the Portuguese sailors. According to the villagers and the clergy, a glass stand on the altar contains the relics of St. Antony sent from Rome to the local bishop Gabrielle Francis Roche in the 1960s. The tiny wooden statue of St. Antony is one of the major spiritual attractions for pilgrims. Every Tuesday - considered sacred since St. Antony died on a Tuesday - pilgrims flock to the shrine to see the wooden statue and St. Antony's relics, the two major spiritual attractions for pilgrims. The two annual festivals, observed in February and mid June, attract tens of thousands of pilgrims of all religious affiliations. According to a conservative estimate, the February festival draws over 100,000 pilgrims from far and near. During the festival season streams of devotees stand in long lines to touch the glass case containing St. Antony's relics or have an item blessed by the saint by placing it on the wooden statue.

\section{B. Saint}

The original St. Antony of Padua, a native of Lisbon but commonly referred to as the saint of Padua since he spent his mature years in the Italian city of Padua, is well known throughout the Catholic world as the "finder of lost articles" and the bestower of fertility. However, Uvari St. Antony is especially renowned for his powers over demonic spirits, particularly malevolent local Hindu deities/spirits like Isaikki Amman and Chutalaimadan who command the religious attention of a vast number of his local Hindu and Catholic devotees. ${ }^{2}$ Although his 
iconography is consistent with St. Antony of Padua's typical representation in the Catholic world where he is portrayed in Franciscan habit holding a book and the infant Jesus in his arms, Uvari Antony's sacred persona and powers are radically recast to reflect indigenous assumptions concerning sacred figures and the existential human and spiritual needs of his local devotees. This recasting enables Uvari Antony's religiously pluralistic clientele to embrace the European saint as their chosen clan or family deity (kula teyvam) equal in power and attributes to such popular Hindu tutelary deities as Mariamman, the Tamil goddess of disease and healing. Called as the Parava saint to distinguish him from St. Antony of Puliampatti where Nadar caste groups constitute his principal clientele, this indigenized saint of European descent both supports and confounds indigenous social realities like caste. "Million, Miracle Worker," "Wonder-worker," and "Superdoctor" are some of Antony's affectionate, popular indigenous titles. So powerful and revered is St. Antony that numerous wayside shrines are dedicated to him throughout the coastal region of southeast Tamil Nadu. In incorporating indigenous traits, the cult of Uvari Antony represents a compelling case of the reconstruction and transformation of a European Catholic saint into a powerful indigenous tutelary deity. Uvari Antony's ability to bring healing to both Hindu and Catholic devotees illustrates the complex negotiations and complicated identities of his devotees and their shared religious universe.

\section{Devotees}

St. Antony's devotees come from all religions, castes, and walks of life, although rural low-caste Hindus and Catholics constitute his principal clientele. They may be classified under two broad types: a) resident devotees comprising local villagers whose identities are linked to the shrine and its saint, and $b$ ) visiting pilgrims who come to the shrine for a brief or extended stay either to establish or strengthen ties with the saint. While the resident devotees are Parava Catholics, the vast majority of the visiting pilgrims come from diverse caste and religious groups with Hindus and Catholics of the Nadar caste group constituting the single largest group. Throughout the year, visiting pilgrims flock to the shrine on Tuesdays to perform vow rituals. Many arrive early in the morning by bus, rented vans, or private cars, spend the day at the shrine to complete the rituals, and return by dusk while others stay in the church guest house for an extended period that can be anywhere from two days to three weeks. As a rile, those suffering from possessions and psychological distress tend to stay for two to three weeks. When at the shrine, devotees are willing to endure hardships such as sleeping on the ground in front of the shrine.

The modes and medium of social and religious interaction between resident devotees and visiting pilgrims merits our attention. Stories and legends about the shrine and the saint provide an entree for initial social interaction between the two groups of devotees that are ordinarily divided by caste, religious, and social distinctions. Thus the saint and the shrine act as the primary reason and medium of interaction/exchange between the two groups of devotees. In this sense, the locals who regard him as a member of their "village family" claiming a filial relationship to him, play host to visiting pilgrims with a feeling of "ownership" since they regard him as "their" saint. The ritual hospitality offered by the villagers to visiting pilgrims is most prominent during the two annual festivals when Uvari residents offer free accommodation in their own homes to pilgrims traveling long distance irrespective of caste distinctions. In the process, the host families subject thernselves to some hardship and inconvenience in hopes of garnering additional spiritual and/or earthly blessings from the saint. Suspending caste distinctions 
for the duration of the festival, the casteconscious Parava Catholics share their home and food with Hindus and Catholics of Nadar caste avoided in daily life. Several villagers proudly told me that they consider it a great honor to extend hospitality to pilgrims. Extending hospitality to pilgrims, they say, is tantamount to offering hospitality to the saint himself. Others view it as a way of expressing gratitude for favors received from the saint. Given that this remote village has limited lodging facilities, the hospitality tradition devised by the laity is an ingenious and pragmatic adjustment to local economic realities. Mutuality and reciprocity characterize the hospitality tradition at Uvari. It yields positive social benefits both to the hosts and the guests as it helps expand their social network. In many cases, new friendships are forged between the host and pilgrim families while in other cases old bonds are renewed and strengthened since host families tend to welcome repeat pilgrims. Pilgrims reciprocate by inviting their hosts to their homes.

\section{The Asanam Ritual Tradition}

Asanam is the most common ritual obligation undertaken by the devotees. The centerpiece of Uvari ritual tradition, asanam, as noted earlier, is a collective term for a series of ritual actions undertaken as promissory, petitionary, or thanksgiving rituals. Ordinarily these include, but are not limited to, fasting, ritual sacrifice of a goat or chicken, hair-shaving, and feeding thirteen beggars/poor persons/destitutes. In the weeks preceding asanam, the sponsor family subjects itself to a series of austerities in order to ensure the efficacy of the rite. Devotees offer asanams for any number of earthly benefits ranging from finding suitable spouses, gaining healing, fertility, marital stability, and agricultural prosperity to passing exams and securing jobs in the Gulf countries. Local tradition maintains that asanam is particularly efficacious for obtaining relief from various physical diseases and psychological problems including possession. Unofficial estimates claim that on an average about 1000 devotees have their hair shaved during the June festival and 5000 during the February festival.

Devotees believe that it is especially meritorious and auspicious if asanam is performed on a Tuesday, since St Antony died on a Tuesday. Church officials state that on average about thirty five to forty asanams take place every Tuesday. While some arrive a day early so that they are spiritually prepared to commence asanam rites with the auspicious early moming purificatory bath at the shrine well known as "puthumai kinaru" (wonder well) believed to have special purificatory and healing powers, most pilgrim families arrive Tuesday morning in buses, taxis, rented vans or buses, and private cars. Devotees take special care to ensure the proper execution of their promises and the prompt payment of debt owed to the saint lest they incur his wrath. Uvari Antony has a reputation to be vengeful and wreak havoc on those who break their promise. "If we don't fulfil our promises" an elderly resident of Uvari commented, "St. Antony will beat us to death. Every night. he goes around the village on a white horse wielding a silver stick. He chases the delinquents and causes misfortune for them. He does not spare even the priests who become greedy over church donations." 3 The transactional idiom implicit in the asanam rites and in the saintdevotee relationship requires a separate treatment which is beyond the purview of this paper (Raj 2004).

The following is the general pattern for asanam rites. The ceremonies begin with a series of preliminary rites that frequently include hair-shaving and ear-piercing in the tonsure house located near the shrine. This is followed by a purificatory bath at the "wonder or miracle well" with thirteen buckets of water drawn from this well. As noted above, the number 13 has special 
religious significance since St. Antony died on June 13: Pilgrims insist that the efficacy of the rite depends, among other things, on the strict adherence to the auspicious number. Although mandatory only for the principal petitioner/beneficiary of Antony's favors, usually other family members also take purificatory baths to express solidarity with the vow-taker since the saint's blessings also accrue to the entire family. Then the sacrificial animal, usually a hegoat or a fowl, is similarly bathed with thirteen buckets of water and garlanded. Accompanied now by family members carrying rice, vegetables, and other items, the devotee and the goat - both drenched in water - circumambulate the shrine thirteen times. When this is concluded, the entire group assembles in front of St. Antony's altar to offer thanks for favor(s) received and to signal its resolve to fulfil the vow promised to the saint. Family members then guide the goat/fowl to the slaughter house located behind the shrine where it is slaughtered and skinned. Whereas the skin is usually donated to the church, the meat is used to prepare an elaborate meal that invariably includes a meat dish. ${ }^{4}$ Devotees pay a nominal fee to the church to rent cooking utensils and space in the large community kitchen. On any Tuesday one can see several pilgrim families, Hindu and Catholic alike, preparing the ritual meal in the community kitchen where all family members - men and women, young boys and girls - help with the preparation of the ritual meal. Sharing communal kitchen space provides an opportunity for these families, particularly women, to share stories about the special favors they have received or hoped to receive from St. Antony which helps reinforce their faith in the efficacy of the rites and the saint's sacral powers. Communal cooking also creates among pilgrims of diverse religions and castes a feeling of spontaneous - albeit temporary communitas across religious and social boundaries. It is not uncommon for pilgrim families to share the ritual meal with fellow pilgrims. When the meal is ready, all those who did not take the purificatory bath earlier in the day now proceed to the miracle well for bath followed by a ceremonial circumambulate of the shrine.

The centerpiece of asanam rites is the festive ritual meal prepared by devotees and offered to St. Antony's "honored" earthly representatives as a thanksgiving gesture for favors already received or as a promissory offering for blessings hoped for. Ordinarily, these "honored guests" are beggars and destitutes selected by the shrine lay staff. Each "guest" is given a meal token that entitles them to the ritual meal. A crucial part of the ritual meal is the rubrics and etiquette governing the feeding of thirteen "honored beggars," a number significant to St. Antony. Family members take special care to treat these thirteen persons with utmost respect, reverence, and honor because, devotees say, they are the saint's "ritual surrogates." Devotees insist that religious identities, caste considerations, and social distinctions do not play, at least for the duration of the ceremonies, any role in the treatment of the guests. A popular legend recounted by an elderly villager stresses this idea: "Many decades ago a poor Harijan [untouchable] man had cooked a meal and offered it to others. Nobody was willing to eat it. He cried before the Lord. He then dug a hole in front of the church, spread some leaves in it, put the food and covered it with leaves. He then covered up the pit and went home." At this point, the village elder's eyes lit up and his voice broke as he related, "Six months later they were digging a pit to hoist the flag for the festival. Vapor rose from the food which was still fresh. Devotees scrambled to eat it. After that incident people accept food here from everybody irrespective of caste, creed, colour or riches" (Nadar 1998). ${ }^{5}$ Those selected for the ritual honor may be Hindus, Muslims, and Catholics. Thus, Hindus may partake of the asanam meal hosted by a Catholic family, and vice versa. During my field research in the summer of 2000 and winter of 2003, I 
attended several asanams where Catholics were fed by Hindu devotees and Hindu and Muslim beggars were fed by Hindu and Catholic devotees.

The pilgrim families themselves have no part or say in who gets selected for the ritual honor. The selection of "guests" is supervised by the shrine's lay staff who determine eligibility, assign a specific pilgrim family, and distribute meal tokens. Tradition requires that those selected represent the poorest of the poor - usually beggars - irrespective of caste and creed. However, today local residents complain about a general decline in the appreciation of the spiritual values and ideals of asanam ritual. According to a long-time parishioner of Uvari, the token system has recently been abused by the shrine lay staff who tend to favor their own friends and relatives. "This takes away the very spirit of asanam meal," he said. ${ }^{6}$ Another villager echoed this sentiment: "Today asanam has lost its spiritual character. It has become a party, an occasion for family get-together and celebrations. The truly deserving are not the ones who receive the meal. In fact, some beggars choose not to go for asanam meal as it causes a dent into their potential revenue from begging.:"7

Asanam tradition requires the vow-taker to serve the food himself/herself to the thirteen honored "ritual guests." As per local custom, the meal is to be served on banana leaves as is the norm for auspicious occasions like weddings. When the meal is served on banana leaves, a thanksgiving prayer is offered to St. Antony. Following this, the vow-taker who is the principal sponsor of the feast kneels in front of the thirteen "honored beggars" and begs for a handful of food from each of them to whom he has just served the meal. With the food collected through reverse begging, s/he sits beside the thirteen beggars, and eats the ritual meal. Only after the "ritual guests" have been fed to their satisfaction, can family members partake of the ritual meal. Asanam rules dictate that the leftovers are not to be taken back home but distributed to the poor. In addition to the meal, some families also offer cash and/or clothing to the "ritual guests."

As we come to the end of this discourse on ritual food illustrated in the asanam rites and review their principal actors, two questions linger in our minds. First, who stands to gain the most from this ritual drama? Second, what does the ritual exchange between Hindus and Catholic devotees reveal about their religious identities and, by extension, the type of dialogue implicit in Hindu-Catholic relationship in Tamil Nadu? Let me therefore close this section with some comments on the ultimate winner of this ritual drama, postponing my reflections on the second question to the final section of this paper.

Evidently, the socially inferior beggar from the street gains a hearty meal and temporary respect and elevation from his social superiors. Through the transgressive ritual meal, he has an opportunity to engage in social commerce with his superiors in the intimate context of eating which otherwise is a ritual and social taboo. The saintly patron the primary focus of the entire ritual receives special honor and devotional attention from his loyal clients as well as public recognition for his sacral powers that in return enhances his spiritual fame and gains him some new devotees. To the shrine, its keepers - clerical and lay - and the institutional church that provide legitimacy and ecclesiastical approval, the asanam tradition brings additional revenue, increased social influence, and greater spiritual power. However, it appears that the devotee who sponsors the meal comes out as the ultimate winner. In addition to garnering the saint's spiritual and earthly blessings for himself and his family, he manages to elevate his spiritual and social status by extending ritual hospitality to the saint through feeding his ritual surrogate. The economic hardships and the temporary reduction in social status predicated by the 
ritual are offset by - indeed far outweigh the spiritual and earthly blessings he reaps from the ritual. Perhaps this is why pilgrim centers like Uvari continue to be such powerful spiritual magnets for the religious masses.

\section{Ritual Food: A Temporary Equalizer of Social and Religious Distinctions?}

What interpretive paradigms might assist us in delineating the social and religious themes embedded in the asanam tradition in general and in its food rituals in particular? Following Claude Levi-Strauss, who maintained that the empirical category of food can reveal a society's intricate set of abstract ideas, anthropologists like Firth (1973: 253, 261) have shown that ritual foods not only serve as social codes revealing a culture's or group's social relationships but also function as social mediators when prepared and consumed in specific ritual contexts by certain categories of people (Thompson 1988: 71-108). ${ }^{8}$ While they often serve to reinforce social relationships and identities, ritual foods can also serve to defy and transcend - albeit temporarily - neatly defined social relationships, codes, and distinctions. Such deliberate transgressions of food rules and etiquette are a way to establish a new mode of relationship or to transform an existing relationship. "These are abundantly evident in the asanam ritual tradition. Victor Turner's structure-anti-structure paradigm and his discussion of role reversal and status elevation rituals elucidated in his seminal work (1969) provide the conceptual framework to interpret this dialectic of reinforcement and transgression of structure.

Turner has argued that the ongoing wellbeing of a society and culture requires periodic excursion into chaos and disorder traditionally accomplished through pilgrimage rituals and religious festivals. For Turner, these provide a context for the breaking out of confining social roles, for the breaking up and mixing up of expected social relations, so that other redemptive possibilities may be glimpsed or briefly experienced (Turner 1974: 231-270; Kinsley: 207). In the asanam tradition, the transgression and mixing up of social relations and religious distinctions is effected through the medium of the ritual meal in such wise that two disparate categories of people, i.e. the socially and economically superior host [ritual donor] and the inferior guest [recipient], are temporarily brought together in the mutually dependent relationship of the donor and donee in which both are simultaneously givers as well as receivers.

Additionally, the reverse or inverse begging in the asanam sequence exhibits the classic traits Turner associates with role reversal and status elevation. As Firth has suggested (1973), begging food especially from a social inferior - in this case, beggars evidently marks a temporary reduction in social status. On the other hand, the beggar who receives ritual honor from his traditionally social and economic superior gains temporary status elevation insofar as the social inferior is treated as social superior with special ritual honor and deference until the meal is completed. In this reverse begging, the usual power differential between the donor and the recipient is deliberately effaced or transgressed if not permanently but at least functionally (Ulrich 2004). The temporary state of liminality that the ritual host and guest find themselves in during the ritual also paves the way for a temporary state of transgression and a mood of communitas among two categories of people between whom such social and ritual interactions are not commonplace. Therefore, it seems to me that one of the social functions served by this rite is its ability to provide the devotees a religious context and ritual platform to temporarily transcend the neatly defined social, caste, and religious identities and strictures that normally define human relationships in south India. It also enables its participants to experiment with socially tabooed 
antistructural interactions and reciprocities in an attempt to temporarily level social and religious differences in order to gain or ensure certain earthly benefits from a spiritual patron.

Such anti-structural ritual expressions of transgressions of social norms and prescriptions and the resulting communitas have positive benefits for the principal actors in this role reversal ritual as well as for the larger society, since these help reaffirm and reinforce social order and distinctions, in our case, the social distinctions of class and caste. "Not only do they [rituals of status reversal] reaffirm the order of structure" writes Turner, "they also restore relations between the actual and historical individuals who occupy positions in that structure" (Turner 1969: 177). Such reversal rituals bring "social structure and communitas into right mutual relations once again" (178). In the final analysis, therefore, the inverse or reverse begging undertaken in the ritual context has the social benefit of reordering structure and reinforcing social hierarchy

A key argument in the Turnerian theory is that role reversal and status elevation rituals help reinforce hierarchy and order insofar as participants return to their socially defined position with a renewed fervor and commitment to upholding structure. In the case of the asanam ritual, it is true that role reversal cements hierarchical order in that at the conclusion of the ritual the beggars resume their pre-ritual humble status as beggars with no palpable or impalpable change in social status. This is evident when they rejoin the beggars' line in front of the shrine soon after the ritual meal. Just as the temporary ritual elevation of the beggars has no enduring impact on their social and economic status, the temporary reduction of status willingly embraced by the ritual hosts does not have significant impact on their post-ritual social and economic status. Like the beggars, the devotees too return to their ascribed or previously held social and economic status. To this extent, Turner's theory is a valuable interpretive tool for decoding the social themes and significance embedded in the reverse begging ritual at Uvari.

The Turnerian theory falls short, however, when it comes to assessing the ritual's religious impact on both Hindu and Catholic devotees. Unlike the beggar - a poster child for Turner's status elevation theory who undergoes only temporary social change - the ritual produces significant attitudinal, behavioral, relational, and perspectival shifts, in many cases permanent and substantive, among the devotees. While most visible when they are in the shrine, these also endure after they return home. ${ }^{9}$ When Hindu and Catholic devotees converge in the shrine, it ushers in a harmonious collision - more precisely, a sort of communion - of religious identities that reveal the fluidity and blurring of boundaries between Hindu and Catholic. At the shrine, religious distinctions are neither dismissed nor forgotten but temporarily obliterated and transcended as irrelevant to their pragmatic human concerns and existential religious experiences. The ongoing relationship of reciprocity and mutuality characteristic of Hindu and Catholic relations among the laity, that gains public manifestation during the role reversal ritual in particular and the asanam ritual sequence in general, is deepened and renewed. This is especially visible in their religious behavior and ritual performance at the shrine when Hindu devotees participate in Catholic rituals like reciting the Hail Mary before the meal and when Catholic devotees perform Hindu-like rituals like animal sacrifice and hairshaving. Through these rituals, both groups demonstrate their new-found shared identity as St. Antony's devotees, an identity that transcends and complements their usual identities as Hindus and Catholics. Furthermore, the ritual food consumed by Hindus and Catholics, and the ritual hospitality shared by the resident Catholic devotees with visiting Hindu pilgrims in the liminal space of the shrine, forge new - often 
lasting - relationships that yield much social dividends beyond the ritual moment and context.

The impact of the ritual is also discernible in the devotees long after they return home. Upon returning home, many Hindu devotees co-opt St. Antony into their pantheon of kula teyvam (clan deity) or ista. devata (chosen deity), enthroning his statue or his picture in their domestic shrines. Others become return pilgrims to the shrine. Similarly, Catholic devotees continue to draw - as and when dictated by existential realities and needs - from the Hindu ritual tradition that defined their transgressive ritual performance at the shrine. The ritual exchange at the shrine also exerts a profound effect on Hindu and Catholic devotees' perceptions and assumptions about themselves, their personal religious identities, and their relationship with "religious others." The "religious other" is not viewed as an alien, stranger, or enemy but as a fellow-pilgrim, as a member of one's "ritual household and fraternity." Their newfound, shared identity as St. Antony's devotees, their pragmatic approach to finding solutions to their shared earthly concerns like health and healing, and their co-dependence on shared sacred figures who resonate with their religious ideas and human needs bring them in a functional, living dialogical relationship. Thus, the asanam tradition renews and strengthens their commitment to and faith in the power, necessity, and efficacy of ritual mutuality and reciprocity, of dialogue on the ground. As such, the asanam meal serves as a metaphor for Hindu-Christian dialogue at the grassroots level. It also serves as a metaphor for the liminality and for the complicated identities and complex relationships between Hindus and Catholics in south India that defy rigid, normative, and institutional definitions.

\section{Dialogue On The Ground: An Alternative Model For Dialogue}

The ritual life of the laity, both Hindu and Catholic; exemplified in the asanam ritual tradition at the shrine of St. Antony at Uvari, serves as a textbook case for dialogue "on the ground." Dialogue "on the ground" refers to the ritual encounter and exchange between Hindu and Catholic laity - often in opposition to and defiance of institutional norms and ecclesial prescriptions - that occurs at the grassroots level in the arena of popular piety and rituals (Dempsey 2000; 2002: 115-139; Raj 1994; Waghorne 2002: 11-37). This type of dialogue gains prominence especially during life-cycle ceremonies and crisis situations such as sudden illness or death. As illustrated above, a salient aspect of this dialogical form is the exchange across religious boundaries. Specifically, at Catholic sacred sites like the shrine of St. Antony at Uvari, Catholics perform a series of rites that either are simply adopted from popular Hinduism or patterned after Hindu rites. These include such devotional exercises as the offering of hair, the sacrifice of animals, and various fertility and healing rites. Conversely, many Hindu devotees at Uvari and elsewhere perform Catholic rituals in Catholic shrines to gain earthly favors and blessings from Catholic sacred figures. These include reciting the Catholic rosary, partaking of the Eucharist, and dedicating an assortment of votive offerings to Catholic saints. Not only do Hindus and Catholics transcend the rigid and apparently impermeable ritual boundaries of their respective traditions, but their ritual performance also reflects an openness to incorporate the religious assumptions that undergird these rituals. The ritual fluidity and hybridity characteristic of popular religion provide clues to the complex relationships and the complicated identities of lay Hindus and Catholics in south India.

At the meta-level, the dialogue on the ground also demonstrates that an extraordinarily productive locus for efficacious dialogue is the world of rituals rather than the sophisticated world of 
theological concepts and categories. Turner (1985) and Driver (1991) have convincingly shown the power of ritual to transform the spiritual and social condition of the performer and the audience. I suggest that the performance of other's rituals has also a transforming effect on one's or a group's individual and collective identity, their understanding of, and attitudes and relationships toward the "other." In this sense, ritual also functions as a medium for encountering the "other" and a model for dialogue on a profoundly experiential and existential level (Raj 2002b: 55-56).

Unlike the contrived, structured, institutional dialogical initiatives engineered and pursued by the religious elite, as a grassroots phenomenon the dialogue on the ground organically emerges from the lived experience, existential concerns, and human/spiritual needs of Catholic laity and their Hindu neighbors with whom they live in daily dialogical relationship. They draw from each other's ritual and religious resources and their common, shared cultural and linguistic data bank. Whereas the conceptual institutional dialogue generally has little or no real impact on the day-to-day experiences and concerns of dialogical partners or religious practitioners, the ritual exchange among the laity, as noted above, effects a certain organic transformation in the participants" perception of the "religious other" that transcends temporal, spatial, ritual, and religious boundaries. Moreover, while institutional dialogical experiments rely heavily on Brahminic and Sanskritic Hinduism, grassroots dialogue draws from popular lay Hinduism. Additionally, whereas the former relies on Hindu textual, metaphysical, theological, and mystical tradition as the axis of dialogue, the latter is grounded in lay ritual, in lay praxis. In short, it is a practice-centered paradigm. More importantly, the institutional model is a contrived, top-down strategy initiated by the elite whereas the dialogue on the ground is a grass-roots experience of the laity or religious masses that organically emerges from their lived experience and human needs. These two dialogical models also reflect the power struggles and tensions between the center and the periphery, between the religious elite and the masses.

\section{Conclusion}

The enduring vitality and pervasiveness of grassroots dialogue offers four valuable insights for interreligious dialogue and the study of religion in India. First, genuine Hindu-Christian dialogue occurs primarily in the existential human and spiritual experiences of the religious folk, in the periphery, rather than in established institutions and their contrived experiments. Second, the efficacious and productive locus for dialogue is the world of rituals rather than the world of theological concepts and categories. Although the institutional model recognizes the efficacy and dialogical value of ritual, it has had only limited success and appeal because of its inherent elitism, and more importantly, because of the church's aggressive missionary approach in the past and, in some instances, even today.

Third, anchored in religious praxis rather than on abstract theological concepts, the dialogue on the ground is preeminently a dialogue of rituals. As I have argued elsewhere (2000: 333-353; 2002b: 55-56), this ritual dialogue is the lived and living ecumenism of the laity. It is dialogue in action. Recent ethnographic studies on popular religion in south India suggest that the dialogical ideals and goals advocated by the religious elite and implemented through institutional experiments are in fact concretely realized, lived, and enacted by the grassroots dialogue in action. Effectively pursued and vigorously defended by the laity - in opposition to institutional norms and ecclesiastical misgivings - this dialogue on the ground is a meta-tradition in its own right organically emerging from its religiously pluralistic context. As such it acts as a corrective and complement to the conceptual, elitist, institutional dialogue that 
has been found wanting, as it tends to be divorced from the existential experiences and concerns of the masses and as an alternative model that is neither arrogant nor one-sided. It calls for a shift in focus away from institutionally contrived, top-down dialogical experiments to bottom-up dialogue on the ground. Finally, the dialogue on the ground discourages "the tendency to draw absolute contrasts or stark oppositions between coexisting groups and ideologies" and challenges absolute, rigid understanding of authenticity, purity, and identity (Dempsey 2000: 4). As such, it calls for a shift in the academic study of religion in general and of Indian religions in particular, a shift away from the traditional focus on sacred text and theological reflections to lived practice.

\section{Notes}

1. I am grateful to Albion College for the Hewlett-Mellon Grant that funded the field-research in the summer of 2000 . A version of this essay was presented at the annual meeting of the Association for Asian Studies in San Diego, CA (March 6, 2004). In this essay, I use "dialogue on the ground" and "grassroots dialogue" as interchangeable categories.

2. The following account paraphrases Isakki Amman legend in circulation in Tirunelveli district in Tamil Nadu. Isakki was born in a devadasi family. When she was a young woman, the local temple pujari visits her often bringing jewels stolen from the temple where he is a pujari. She refuses to accept them but her mother compels her to accept them. As a result, a relationship. develops between the pujari and
Isakki who became pregnant. Upon hearing that she was pregnant, the pujari kills her by hitting her with a rock and pushing her into a well. Not long after the pujari also dies. $\mathrm{He}$ is rebom in a chettiar (merchant caste) family. Isakki who was also reborn takes revenge on the chettiar family and the entire chettiar village. She is called neeli and thusta devatai (evil goddess). Menstruating and pregnant women are forbidden to pass by her shrine. Black bangles, saris, and thread and oil are the common items offered to Isakki Amman. Women seeking a child usually tie black bangles on the doors of her temple/shrine in hopes of getting a child. The usual sacrificial items include pigs and goats. Oral tradition claims that she is an avatar, incarnation of goddess Parvati. Although Isakkai Amman and Chutalaidaimadan are frequently placed next to each other in many village temples and are the two most feared village deities in Tirunelveli district, there is no relationship between these two deities. Chutalimadan is considered locally as one of the sons of Siva born from his third eye. Isakkai Amman is a destructive, vengeful goddess but she is also believed to be protective of her devotees and those who please her through animal sacrifices. In her ambivalence, she resembles another local goddess in Tamil Nadu, Mariamman, the goddess of disease and healing. (Based on interview with a temple priest at an Isakki 
Amman temple near Nagercoil on June 13, 2000).

3. Interview with Marion Courier at Uvari, June 4, 2000.

4. Though the vast majority of devotees comes from humble and modest economic situations, asanam meals are generally quite elaborate that includes a meat dish, rice, and two or more vegetarian dishes. For example, during my field-research I met at least two families that had brought seventy five kilos of rice for the asanam meal.

5. I have heard a nearly identical story related at the shrine of St.
John de Britto (Raj, 1994: 150151).

6. Interview with Thomas on June 6,2000 .

7. Interview with Harold on June 6,2000 .

8. Thompson's thorough analysis of Chinese funerary rites provides ethnographic support for this argument.

9. I am grateful to my colleague Bindu Madhok for her insightful observations that aided this analysis. 